\title{
Short-term community dynamics in seasonal and hyperseasonal cerrados
}

\author{
Cianciaruso, $M V^{\mathrm{a} *}$ and Batalha, $M A .^{\mathrm{b}}$

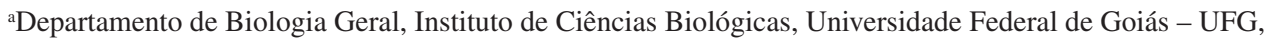 \\ CP 131, CEP 74001-970, Goiânia, GO, Brazil \\ 'Departamento de Botânica, Universidade Federal de São Carlos - UFSCar, \\ CP 676, CEP 13565-905, São Carlos, SP, Brazil \\ *e-mail: cianciaruso@gmail.com
}

Received December 4, 2006 - Accepted August 2, 2007 - Distributed May 31, 2009

(With 4 figures)

\begin{abstract}
In South America, the largest seasonal savanna region is the Brazilian cerrado. Our aim was to study temporal changes in some community descriptors, such as floristic composition, richness, species density, plant density, and cylindrical volume, in a seasonal cerrado, comparing it to a nearby hyperseasonal cerrado. In four different seasons, we placed randomly ten $1 \mathrm{~m}^{2}$ quadrats in each vegetation form and sampled all the vascular plants. Seasonal changes in floristic composition, species density, and plant density were less pronounced in the seasonal than in the hyperseasonal cerrado. Floristic similarity between the vegetation forms was lower when the hyperseasonal cerrado was waterlogged. Richness and species density were higher in the seasonal cerrado, which reached its biomass peak at mid rainy season. The hyperseasonal cerrado, in turn, reached its biomass peak at early rainy season and, despite the waterlogging, maintained it until late rainy season. In the hyperseasonal cerrado, waterlogging acts as an environmental filter restricting the number of cerrado species able to withstand it. The seasonal cerrado community was more stable than the hyperseasonal one. Our results corroborated the idea that changes in the environmental filters will affect floristic composition and community structure in savannas.
\end{abstract}

Keywords: diversity, Emas National Park, hyperseasonality, savanna, seasonality.

\section{Seca e alagamento como determinantes da dinâmica da comunidade de cerrados estacional e hiperestacional}

\begin{abstract}
Resumo
Na América do Sul, a maior região de savana é o cerrado brasileiro. Estudamos as mudanças na composição florística, riqueza, densidade de espécies, densidade de plantas e volume cilíndrico em um cerrado estacional comparando-o com um cerrado hiperestacional adjacente. Em quatro estações do ano, sorteamos dez parcelas de $1 \mathrm{~m}^{2} \mathrm{em}$ cada formação vegetal, nas quais amostramos todas as plantas vasculares. Mudanças estacionais na composição florística, densidade de espécies e densidade de plantas foram menos pronunciadas no cerrado estacional. A similaridade entre os cerrados foi menor quando o cerrado hiperestacional estava alagado. A riqueza e a densidade de espécies foram maiores no cerrado estacional, que atingiu o pico de biomassa no meio da estação chuvosa. O cerrado hiperestacional, por sua vez, atingiu o pico de biomassa no começo da estação chuvosa e, apesar do alagamento, o manteve até o final da estação chuvosa. No cerrado hiperestacional, o alagamento atua como um filtro ambiental restringindo o número de espécies de cerrado capazes de tolerá-lo. A comunidade do cerrado estacional foi mais estável que a do cerrado hiperestacional. Nossos resultados corroboraram a idéia de que mudanças de curto prazo nos filtros ambientais das savanas afetam a sua composição florística e estrutura.
\end{abstract}

Palavras-chave: diversidade, Parque Nacional das Emas, hiperestacionalidade, savana, estacionalidade.

\section{Introduction}

Plant-available moisture (PAM) is one of the crucial ecological limitations for the growth of savanna plants, varying both spatially, according to depth, and temporally, as a result of seasonal rainfall (Sarmiento, 1996; Silva, 1996). In seasonal savannas, soil water potentials are above the permanent wilting point during the rainy season and, consequently, water is available for any plant species (Sarmiento, 1996; Quesada et al., 2004; Oliveira

et al., 2005). During the dry season, soil water potentials may remain for some months at values as low as the permanent wilting point, still within the reach of woody plants, but not of herbaceous ones (Franco and Nobel, 1990; Sarmiento, 1996; Franco, 2002). Drought causes water deficit in plants, affecting metabolism and morphology, reducing growth, and arresting development (Baruch, 1994). Thus, drought represents one marked 
stressing moment for several cerrado plants, since it drastically affects herbaceous vegetation with superficial roots (Sarmiento, 1996). There may be a great seasonality in soil water content at $0-20 \mathrm{~cm}$ in cerrado sites, which reaches its lowest amount in the dry season and its highest in the rainy season (Quesada et al., 2004).

Hyperseasonal savannas experience additionally a second stressing moment in the rainy season. In hyperseasonal savannas, a PAM-limited dry season alternates with a rainy season during which soil is saturated and even waterlogged (Sarmiento, 1996; Sarmiento et al., 2004; Cianciaruso et al., 2005). During waterlogging, gas exchange between soil and air decreases, as gas diffusion in water is decreased 10,000-fold (Malik et al., 2001). Oxygen in the soil is rapidly depleted, and the soil may become hypoxic or anoxic within a few hours (Malik et al., 2001). These effects become more pronounced during prolonged periods of waterlogging, lasting weeks or months, but even short-term, transient waterlogging (lasting hours or days) can have considerable effects on plant growth (Leyshon and Sheard, 1974; Jackson, 1979). Hypoxia or anoxia are the main limiting factors that reduce aerobic respiration and the absorption of minerals and water by roots, causing a rapid decrease of photosynthesis rate (Baruch, 1994). Even if waterlogging does not kill vegetation, it influences the competitive abilities of plants, since the severe physiological stress may lower the competitive abilities of plants that would be highly competitive under drier conditions (Jackson and Drew 1984).

In the Neotropics, the most widespread savanna type are seasonal savannas, where an extended rainless season increases fire frequency; and then, drought and burning provide a neat rhythmicity in community functioning (Sarmiento, 1984). Hyperseasonal savannas, in turn, are characterised by the alternation of two contrasting stresses during each annual cycle - one induced by drought and fire, the other, by waterlogging - and normally occur on poorly drained bottomlands or depressed regions with slow and ill-defined drainage, especially in the Bolivian and Venezuelan llanos (Sarmiento, 1984).

The cerrado is by far the largest savanna region in South America, originally covering about two million $\mathrm{km}^{2}$, or $23 \%$, of the Brazilian territory (Ratter et al., 1997), mainly in the Central Plateau. The climate is seasonal, with wet summers and dry winters, classified either as Aw or Cwa following Köppen's (1931) system. The dry season is quite pronounced and, in some cases, may last six months (Ratter et al., 1997). Rainfall is highly seasonal, with about $90 \%$ occurring in the wet season, from October to April, whereas the dry season has close to zero rainfall in some months, with air humidity less than 20 percent in August and September (Ratter et al., 1997; Quesada et al., 2004). Temporary waterlogging is very restricted in cerrado vegetation, which is basically seasonal (Sarmiento, 1984). Waterlogged savannas are poorly known, since the relatively low species richness and the inhospitable working conditions make these areas unattractive for fieldwork, which might be the reason for their knowledge status (Kier et al., 2005). Nevertheless, we related the first occurrence of a hyperseasonal cerrado recently, in Emas National Park (ENP), central Brazil (Batalha et al., 2005; Cianciaruso et al., 2005).

In a previous study in the hyperseasonal cerrado of ENP, with the same experimental design used here, we found that this community is highly dynamic on a temporal scale (Cianciaruso et al., 2005). The hyperseasonal cerrado community is dynamic due to waterlogging in mid rainy season which reduces species and plant density, whereas drought reduces diversity (Cianciaruso et al., 2005). In the early rainy season, though, species density, plant density, and diversity increase (Cianciaruso et al., 2005). In ENP, the hyperseasonal cerrado is surrounded by a seasonal cerrado that is never waterlogged. The duration of waterlogging in the hyperseasonal cerrado is not long enough to alter its soil characteristics and limitations to the plants growing on it must be a consequence of the direct effects of flooding (Amorim and Batalha, 2006). Within this framework, we have a suitable situation to test the waterlogging effects in a community located in a region where the majority of species are known to not be able to withstand waterlogging conditions (Joly, 1991; Ratter et al., 1997), but are well recognised to be able to support drought (Ratter et al., 1997; Quesada et al., 2004). Here our aim was to study temporal changes in some community descriptors of a seasonal cerrado, comparing it with our previous results in a nearby hyperseasonal cerrado (Cianciaruso et al., 2005). We were also interested in possible changes in floristic composition of the seasonal and hyperseasonal cerrados throughout the year. We tested the postulate that the relative stability of a community in the face of a perturbation depends on its floristic composition (Silva, 1996). Stability can be exhibited by different community properties, such as floristic composition, including not only species combinations, but also diversity, demographic patterns, total biomass, cover, and similar system properties (Archer et al., 1996). As long as there are two stresses, drought and waterlogging, in the hyperseasonal cerrado, we expected larger variation in its floristic composition and community structure throughout the year than in the seasonal cerrado. In other words, we expected the seasonal savanna to be more stable than the hyperseasonal one. So, we tried to answer the following questions: i) does the floristic composition vary in the same way throughout the year in the seasonal and hyperseasonal cerrados?; ii) is the floristic composition of the hyperseasonal cerrado (Cianciaruso et al., 2005) less similar to the seasonal cerrado when the former is waterlogged?; iii) is the seasonal cerrado savanna richer in species than the hyperseasonal cerrado?; iv) does species richness vary throughout the year in seasonal and hyperseasonal cerrados?; and v) do species density, plant density, and cylindrical volume vary in the seasonal cerrado similarly as we previously found in the hyperseasonal cerrado (Cianciaruso et al., 2005)? 


\section{Material and Methods}

\subsection{Study area and data}

We carried out this study in Emas National Park (ENP), one of the largest and most important reserves in the Cerrado region, of 132,941 ha. The Emas National Park is located in the Brazilian Central Plateau, southwestern Goiás state, and was included by Unesco (2001) in the World Natural Heritage List as one of the sites containing fauna, flora, and key habitats that characterise the cerrado. Regional climate is classified as Aw according to Köppen (1931), being humid tropical with wet summer and dry winter. The dry season goes from June to August and the wet season, from September to May (Figure 1). Annual rainfall varies from 1,200 to 2,000 mm, concentrated from October to March, and mean annual temperature lies around $24.6{ }^{\circ} \mathrm{C}$ (Ramos-Neto and Pivello, 2000). The Fazenda Paineiras Meteorological Station of the Brazilian Agrometeorological System, located approximately $10 \mathrm{~km}$ from the study area, provided the monthly rainfall, soil water availability, and air temperature values within the study period. During this period, total rainfall was $1,531 \mathrm{~mm}(89 \%$ from October to April). The soil water content from the superficial soil layer follows the seasonal pattern of rainfall (Pearson's correlation, $r=0.78, p=0.002$; Figure 1 ).

In ENP, open cerrado physiognomies prevail, almost all characterized as seasonal savannas, covering $68.1 \%$ of the total area (Ramos-Neto and Pivello 2000). Physiognomically, the two studied areas are similar: grasslands, with few scattered shrubs and dwarf trees. The hyperseasonal cerrado, in the southwestern portion of the reserve, covers ca. 300 ha and its most abundant species is the grass Andropogon leucostachyus (Batalha et al., 2005; Cianciaruso et al., 2005). At the end of the rainy season (from February to April), the water table rises up to $0.2 \mathrm{~m}$ above soil level, whereas, in the dry season (from June to August), there is a water shortage in the upper soil layers. In the seasonal cerrado, the grass Tristachya leiostachya is the most abundant species (Ramos-Neto and Pivello, 2000). Both communities are on nutrient-poor soils, classified as Oxisols, with higher aluminium saturation, lower base saturation, high percentage of sand, and low values of $\mathrm{pH}$, organic matter, and phosphorus (Amorim and Batalha, 2006).

We carried out four surveys in the seasonal cerrado (approximately, $18^{\circ} 17^{\prime} 34^{\prime \prime} \mathrm{S}$ and $52^{\circ} 58^{\prime} 12^{\prime \prime} \mathrm{W}$ ) and in the hyperseasonal cerrado (approximately, $18^{\circ} 18^{\prime} 07^{\prime \prime} \mathrm{S}$ and $52^{\circ} 57^{\prime} 56^{\prime \prime} \mathrm{W}$ ): in February 2003, in mid rainy season, when the hyperseasonal cerrado was waterlogged; in May 2003, in late rainy season; in August 2003, in the dry season; and in November 2003, in early rainy season. We delimited a 1 ha area, placing randomly ten $1 \mathrm{~m}^{2}$ quadrats in each field trip and counting the number of individuals of each vascular plant except seedlings. In the case of cespitose grasses and sedges, we considered as an individual the whole tuft. We measured the height and diameter of each individual at soil level and counted the number of individuals belonging to each species. We identified the species by comparing the collected material to lodged vouchers, mainly the ENP's reference material collected by Batalha and Martins (2002), but also vouchers lodged at the São Paulo Botanical Institute, IBGE, and University of Brasília herbaria. When identification at species level was not possible, we, or taxonomists, classified them as morphospecies.

\subsection{Data analysis}

To compare the floristic compositions, we constructed a matrix with the species abundance of each survey in the seasonal and hyperseasonal cerrados and did a non-metric multidimensional scaling (NMDS) (Faith et al., 1987; Clarke, 1993), using PAST software (Hammer et al., 2001). We calculated the dissimilarities between all pairs of samples using the Bray-Curtis dissimilarity measure (Bray and Curtis, 1957), a robust measure in recovering ecological distance (Faith et al., 1987; Anderson et al., 2003). How good the graphical representation of the dissimilarity matrix is can be determined by the 'stress value' (Kruskal, 1964). Clarke (1993) recommended a stress threshold of 0.2 , above which misleading interpretations are likely; therefore, we used this to accept ordination configurations. NMDS has been demonstrated as a robust and usefully unconstrained ordination procedure for Ecology (Anderson et al., 2003). We used a non-parametric multivariate analysis of variance (Anderson, 2001) and pair-wise a posteriori test, both with 4,999 permutations, to test for significant differences $(\alpha=0.05)$, using the NPMANOVA software (Anderson, 2003). We corrected the pair-wise $\mathrm{P}$ values for multiple comparisons with the Bonferroni method.

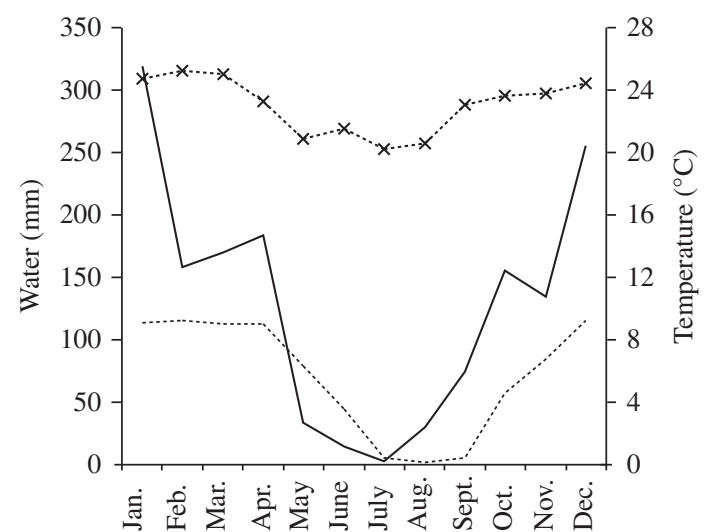

$$
\begin{gathered}
\text { Rainfall ....... Soil water availability } \\
\text {....... Mean temperature }
\end{gathered}
$$

Figure 1. Monthly rainfall, soil water availability, and temperature throughout the year (2003) in Emas National Park region. Data from Paineiras Farm Meteorological Station of the Brazilian Agrometeorological System, located approximately $10 \mathrm{~km}$ from the study area. 
We also estimated floristic similarity among seasons between seasonal and hyperseasonal cerrados with the abundance-based Chao estimator for Sørensen index (Chao-Sørensen), which reduces undersampling bias by estimating and compensating for the effects of unseen, shared species (Chao et al., 2005). This index is better suited than the corresponding classic Sørensen index for assessing compositional similarity between samples that differ in size, are known or suspected to be undersampled, or are likely to contain numerous rare species (Chao et al., 2005). We calculated the Chao-Sørensen index with $95 \%$ confidence intervals (CI), using EstimateS 7.5 software (Colwell, 2005).

To compare the community structure, we analysed the following variables: species richness, species density, plant density, and cylindrical volume. We defined species richness as the number of species sampled, species density as

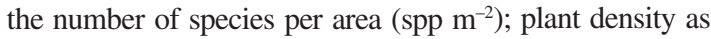
the number of individuals per area (ind $\mathrm{m}^{-2}$ ); and cylindrical volume as the volume (basal area $\mathrm{x}$ height) occupied by each species $\left(\mathrm{m}^{3} \mathrm{~m}^{-2}\right)$. For the hyperseasonal cerrado, these descriptors, with the exception of species richness, are already published in Cianciaruso et al., (2005). We calculated an individual-based rarefaction curve with $95 \% \mathrm{CI}$ curves using the $S_{\text {obs }}$ (Mao-Tau) function (Colwell et al., 2004) to compare the number of species we found, that is, species richness in each season, using the EstimateS 7.5 software (Colwell, 2005). We also compared the total species richness (i.e., number of species in all seasons) between seasonal and hyperseasonal cerrados with the same procedure. As long as species density, plant density, and cylindrical volume were not normally distributed, we log-transformed these data prior to the analyses. We used a two-way ANOVA and Tukey multiple comparisons test (Zar, 1999) to test for significant differences $(\alpha=0.05)$, with 'vegetation form' being the first factor and 'season', the second one.

\section{Results}

Using the floristic data from all field trips, we found 107 species and 31 families in the seasonal cerrado and 64 species and 19 families in the hyperseasonal cerrado (see Cianciaruso et al., 2005; Silva and Batalha 2006 for the species list). We found 19 species not previously related in the ENP flora, nine in the seasonal cerrado and ten in the hyperseasonal cerrado (Table 1). Moreover, we found 20 species (Table 1) that were not previously related for the Cerrado flora (Mendonça et al. 1998). The most representative families in both areas were Poaceae and Myrtaceae, followed by Fabaceae and Asteraceae in the seasonal cerrado and Asteraceae and Fabaceae in the hyperseasonal cerrado. In the seasonal cerrado, the grass Tristachya leiostachya presented the highest percentages of total cylindrical volume throughout the year, ranging from $66.9 \%$ in the late rainy season to $80.1 \%$ in the early rainy season. In the hyperseasonal cerrado, the grass Andropogon leucostachyus presented the highest percentages of total cylindrical volume throughout the year, ranging from $65.7 \%$ in late rainy season to $98.9 \%$ in mid rainy season. Whereas we found 844 T. leiostachya individuals in the seasonal cerrado, we found only nine in the hyperseasonal one. On the other hand, we found only three individuals of A. leucostachyus in the seasonal cerrado against 1,219 individuals in the hyperseasonal cerrado.

We found a high dissimilarity between the cerrados, with a higher dissimilarity within hyperseasonal cerrado groups than those of the seasonal cerrado (Figure 2). The 'stress value' was 0.18 , validating, thus, the ordination. Assemblages of organisms in seasonal and hyperseasonal cerrados were significantly different in all seasons $(\mathrm{P}=0.002$; Figure 2). For the seasonal cerrado, only the mid rainy season group was significantly different from the other groups, whereas, for the hyperseasonal cerrado, early and mid rainy season were different to the other ones (Figure 2). Overall species richness was higher in the seasonal $(107 \pm 7)$ than in the hyperseasonal cerrado (64 \pm 6$)$. In the seasonal and hyperseasonal cerrados, we sampled, respectively, 55 and 18 species in February (mid rainy season), 58 and 32 species in May (late rainy season), 51 and 26 species in August (dry season), and 61 and 37 species in November (early rainy season). We found the lowest similarity between the two vegetation forms in mid rainy season (Chao-Sørensen index $=0.17 \pm 0.07$ ) and the highest in the early rainy season (Chao-Sørensen index $=0.85 \pm 0.09$ ).

We found significant differences between vegetation forms and among seasons for all community descriptors (Table 2). Species richness and species density were always higher in the seasonal cerrado, and we found seasonal changes only in the hyperseasonal cerrado (Table 2; Figure 3 and Figure 4). In the hyperseasonal cerrado, the lowest species richness was during mid rainy season and the highest, in early rainy season (Figure 3). We did not find interaction between the two factors for plant density (Table 2). Plant density changed seasonally only in the hyperseasonal cerrado and was significantly different between the vegetation forms only at mid rainy season (Figure 4). We did not find interaction between the two factors for cylindrical volume (Table 2), which varied seasonally in both vegetation forms (Table 2; Figure 4). In the hyperseasonal cerrado, cylindrical volume was higher throughout the rainy season and, in the seasonal cerrado, at mid and late rainy seasons (Figure 4).

\section{Discussion}

The floristic similarity between the seasonal and hyperseasonal cerrados was low, showing that the two contrasting stresses (drought and waterlogging) in the latter limit the number and the distribution of species able to grow in those conditions, reflecting the physiological incapacity of most cerrado species in tolerating waterlogging (Batalha et al., 2005; Cianciaruso et al., 2005). We found 19 species not previously related in the ENP flora. Batalha and Martins (2002) had already stated that the number of species in the ENP could be increased by species not found in their survey, since floristic surveys certainly miss a number of species in a given area, especially those that are not at reproductive 
Table 1. Species found in the seasonal cerrado ( $18^{\circ} 17^{\prime} 34^{\prime \prime} \mathrm{S}$ and $\left.52^{\circ} 58^{\prime} 12^{\prime \prime} \mathrm{W}\right)$ and hyperseasonal cerrado $\left(18^{\circ} 18^{\prime} 07^{\prime \prime} \mathrm{S}\right.$ and 52 57' 56" W), Emas National Park, Goiás, central Brazil, which are in addition to ENP's flora (a), that is, not reported by Batalha and Martins (2002), and in addition to the Cerrado flora (b), that is, not reported by Mendonça et al. (1998). For the complete species list of these areas, see Cianciaruso et al. (2005) and Silva and Batalha (2006).

\begin{tabular}{|c|c|c|}
\hline Family/ Species & Seasonal & Hyperseasonal \\
\hline \multicolumn{3}{|l|}{ AMARANTHACEAE } \\
\hline Froelichia procera (Seub. and Mart.) Pedersen ${ }^{\mathrm{b}}$ & $\mathrm{x}$ & $\mathrm{x}$ \\
\hline Annona warmingiana Mello-Silva and Pirani ${ }^{\mathrm{b}}$ & $\mathrm{x}$ & - \\
\hline \multicolumn{3}{|l|}{ ASTERACEAE } \\
\hline Aspilia leucoglossa Malme & $\mathrm{x}$ & - \\
\hline Asteraceae $\mathrm{sp} .1^{\mathrm{a}}$ & - & $\mathrm{x}$ \\
\hline Asteraceae sp. $2^{\mathrm{a}}$ & $\mathrm{x}$ & - \\
\hline Calea clausseniana Baker $^{\mathrm{b}}$ & $\mathrm{x}$ & - \\
\hline Emilia coccinea (Sims) G. Don ${ }^{\mathrm{b}}$ & - & $\mathrm{x}$ \\
\hline Eupatorium campestre DC. ${ }^{\mathrm{b}}$ & - & $\mathrm{x}$ \\
\hline Wedelia macedoi H.Rob. ${ }^{\text {b }}$ & $\mathrm{x}$ & - \\
\hline \multicolumn{3}{|l|}{ FABACEAE } \\
\hline Eriosema crinitum (Kunth) G. Don ${ }^{\mathrm{b}}$ & $\mathrm{x}$ & - \\
\hline Galactia dimorpha Burkart $^{\mathrm{b}}$ & $\mathrm{x}$ & $\mathrm{x}$ \\
\hline Ipomea procurrens Meins. ${ }^{\mathrm{b}}$ & - & $\mathrm{x}$ \\
\hline \multicolumn{3}{|l|}{ LAMIACEAE } \\
\hline Hyptis adpressa A.St.-Hil. ex Benth. ${ }^{\text {b }}$ & $\mathrm{x}$ & $\mathrm{x}$ \\
\hline Hyptis villosa Pohl ex Benth. ${ }^{\mathrm{b}}$ & $\mathrm{x}$ & - \\
\hline \multicolumn{3}{|l|}{ LYTHRACEAE } \\
\hline Cuphea sp. ${ }^{\mathrm{a}}$ & - & $\mathrm{x}$ \\
\hline \multicolumn{3}{|l|}{ MALVACEAE } \\
\hline Waltheria douradinha A. St.-Hil. ${ }^{\mathrm{b}}$ & $\mathrm{x}$ & - \\
\hline \multicolumn{3}{|l|}{ MYRTACEAE } \\
\hline Eugenia livida O.Berga & - & $\mathrm{x}$ \\
\hline Myrciaria delicatula (DC.) O.Berg ${ }^{\mathrm{b}}$ & $\mathrm{x}$ & $\mathrm{x}$ \\
\hline Myrtaceae sp. $1^{\mathrm{a}}$ & - & $\mathrm{x}$ \\
\hline Myrtaceae sp. $2^{\mathrm{a}}$ & $\mathrm{x}$ & - \\
\hline Myrtaceae sp. $3^{\mathrm{a}}$ & $\mathrm{x}$ & - \\
\hline Psidium laruotteanum Cambess. $^{\mathrm{b}}$ & $\mathrm{x}$ & - \\
\hline Psidium guineense $\mathrm{Sw} .{ }^{\mathrm{b}}$ & $\mathrm{x}$ & - \\
\hline \multicolumn{3}{|l|}{ POACEAE } \\
\hline Leptosaccharum filiforme (Hack.) Filg. a, b & $\mathrm{x}$ & - \\
\hline Panicum parvifolium Lam. ${ }^{\mathrm{a}}$ & - & $\mathrm{x}$ \\
\hline Paspalum lineare Trin. ${ }^{\mathrm{a}}$ & $\mathrm{x}$ & - \\
\hline Poaceae sp. $1^{\mathrm{a}}$ & - & $\mathrm{x}$ \\
\hline Poaceae sp. $2^{\mathrm{a}}$ & - & $\mathrm{x}$ \\
\hline Poaceae sp. $3^{\mathrm{a}}$ & - & $\mathrm{x}$ \\
\hline Poaceae sp. $4^{\mathrm{a}}$ & - & $\mathrm{x}$ \\
\hline Poaceae sp. $5^{\mathrm{a}}$ & $\mathrm{x}$ & - \\
\hline Poaceae sp. $6^{\mathrm{a}}$ & $\mathrm{x}$ & - \\
\hline Poaceae sp. $7^{\mathrm{a}}$ & $\mathrm{x}$ & - \\
\hline Rynchelytrum repens Willd. ${ }^{\mathrm{b}}$ & $\mathrm{x}$ & $\mathrm{x}$ \\
\hline Trachypogon $\mathrm{sp}^{\mathrm{a}}$ & $\mathrm{x}$ & - \\
\hline Tristachya leiostachy $\mathrm{Nees}^{\mathrm{a}}$ & $\mathrm{x}$ & - \\
\hline \multicolumn{3}{|l|}{ SAPOTACEAE } \\
\hline Pradosia brevipes (Pierre) T.D.Penn. ${ }^{\mathrm{b}}$ & $\mathrm{x}$ & - \\
\hline \multicolumn{3}{|l|}{ SCROPHULARIACEAE } \\
\hline Scoparia dulcis L. ${ }^{\mathrm{b}}$ & - & $\mathrm{x}$ \\
\hline \multicolumn{3}{|l|}{ TURNERACEAE } \\
\hline Piriqueta emasensis Arbo $^{\mathrm{b}}$ & $\mathrm{x}$ & - \\
\hline \multicolumn{3}{|l|}{ Unknown } \\
\hline Unknown $^{\mathrm{a}}$ & - & $\mathrm{x}$ \\
\hline
\end{tabular}




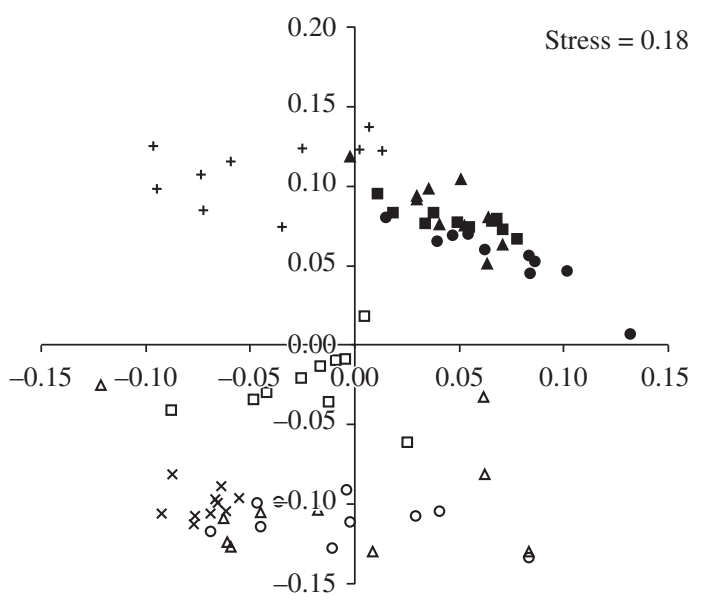

\begin{tabular}{|llll|}
\hline$\times$ hsc Feb. & $\Delta$ hsc May & $\circ$ hsc Aug. & $\square$ hsc Nov. \\
+ sc Feb. & $\Delta$ sc May & $\bullet$ sc Aug. & sc Nov. \\
\hline
\end{tabular}

Figure 2. Non-metric multidimensional scaling (NMDS) ordination diagramme of floristic composition of the hyperseasonal cerrado (hsc) and seasonal cerrado (sc), in Emas National Park, central Brazil, in four seasons. Feb.) February, mid rainy season; May) late rainy season; Aug.) August, dry season; and Nov.) November, early rainy season. Seasonal and hyperseasonal groups were significantly different $(P=0.0001)$. Within the seasonal cerrado, only mid rainy season was different than the other seasons $(\mathrm{P}=0.0002)$. Within the hyperseasonal cerrado, early and mid rainy season were significantly different ( $\mathrm{P}=0.0001$ and $\mathrm{P}=0.0002$, respectively) than late rainy season and dry season, which did not differ $(\mathrm{P}=0.2124)$.

stage at the time of the visit, flower sporadically, are ephemeral, or are inconspicuous, problems that particularly affect the herbaceous component of the vegetation. According to Castro et al., (1999), there is an almost complete absence of studies that have sampled the herbaceous component in cerrado, in spite of its high richness. In this sense, we found 20 species not reported for the Cerrado domain flora (Mendonça et al., 1998), reinforcing the poor knowledge of cerrado herbaceous species.

Short-term changes and period pulsation of plantavailable moisture may alter species composition and diversity (Sarmiento, 1996), since individuals from different species react differently to changes in their environment and affect survival and fertility at population level (Silva, 1996). Where the environmental situations are seasonal, as in savannas, species are adapted to dynamism and evolve strategies for responding to shifting opportunities (Fjeldsaå and Lovett, 1997). Consequently, the interaction and occurrence of several environmental factors in savannas should have adapted savanna species to withstand many ecological restrictions (Sarmiento and Monasterio, 1975), even the environmental constraints resulting from drought and waterlogging in the hyperseasonal savannas.

Of the 131 species we found in both areas, 22 occurred exclusively in the hyperseasonal cerrado, which is approxi- mately one third of its flora. Waterlogging in hyperseasonal cerrado assembles phylogenetically unrelated species that have converged on similar habitat-use. As a consequence, the habitat-use of the hyperseasonal cerrado is a trait widespread in the phylogeny of cerrado species (Silva and Batalha, 2006). Moreover, only $16 \%$ of the species occurring in the hyperseasonal cerrado might be found as phanerophytes in other cerrado areas, in contrast to $30 \%$ of the species in the seasonal cerrado. So, among cerrado species, mainly the herbaceous ones should be able to withstand temporary waterlogging. Seasonal changes in floristic composition were more pronounced in the hyperseasonal cerrado. As in nearby seasonal and hyperseasonal savannas in the Venezuelan llanos (Sarmiento and Vera, 1979), the hyperseasonal cerrado was less similar to the nearby seasonal cerrado at mid rainy season, when the former was waterlogged, and more similar at early rainy season.

In the seasonal cerrado, species richness and species density were always higher than in the hyperseasonal cerrado. Indeed, seasonal savannas are richer in species than hyperseasonal ones (Sarmiento and Vera, 1979; Sarmiento et al., 2004). The seasonally inundated hydrologic savannas that are common in the north of the Amazon are also, as with the hyperseasonal cerrado, species-poor communities (Ratter et al., 1997). Whereas we found seasonal changes for species richness and species density in the hyperseasonal cerrado (Cianciaruso et al., 2005), higher in early rainy season and lower when it was waterlogged, we did not find them in the seasonal cerrado, highlighting the increased seasonality in the former as a consequence of its two contrasting stresses (Sarmiento, 1984; Sarmiento et al., 2004, Cianciaruso et al., 2005). Similarly, we found seasonal changes for plant density only in the hyperseasonal cerrado (Cianciaruso et al., 2005). Its lower values of species richness and species de nsity, as well as of plant density when it was waterlogged, also indicated the non-adaptation of most cerrado species in tolerating waterlogging.

At any single moment, most species within communities are uncommon. Nonetheless, these uncommon species may play critical roles by becoming dominant following particular environmental triggers (Lyons et al., 2005). In highly stressed communities, resource availability limits the number of co-occurring species with similar ecological requirements; therefore, only those species highly adapted to the stressing factor survive (Baruch et al., 1996). This seems to be true concerning the regional pool of species in the seasonal cerrado, where rare species may become dominant when environmental conditions change, as in the hyperseasonal cerrado, when the waterlogging period appears. Waterlogging may act as an environmental filter (Chase, 2003), restricting the number of cerrado species, on the one hand, and favoring those few species able to withstand the waterlogging, such as A. leucostachyus, on the other. Besides, dominance spectra in herbaceous layer of tropical savannas frequently show a high degree of dominance by a few grass species (Sarmiento, 1984). The dominance of T. leiostachya in the seasonal cerrado is probably due to frequent fires that usually burn large portions of the ENP 


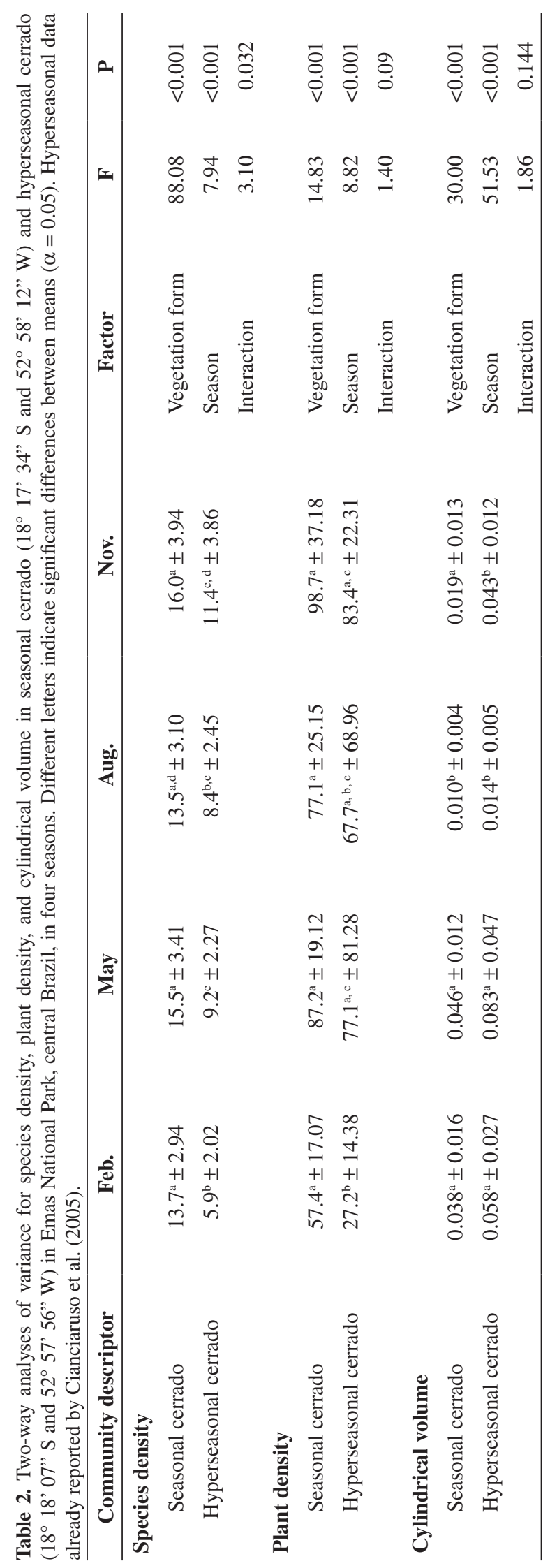



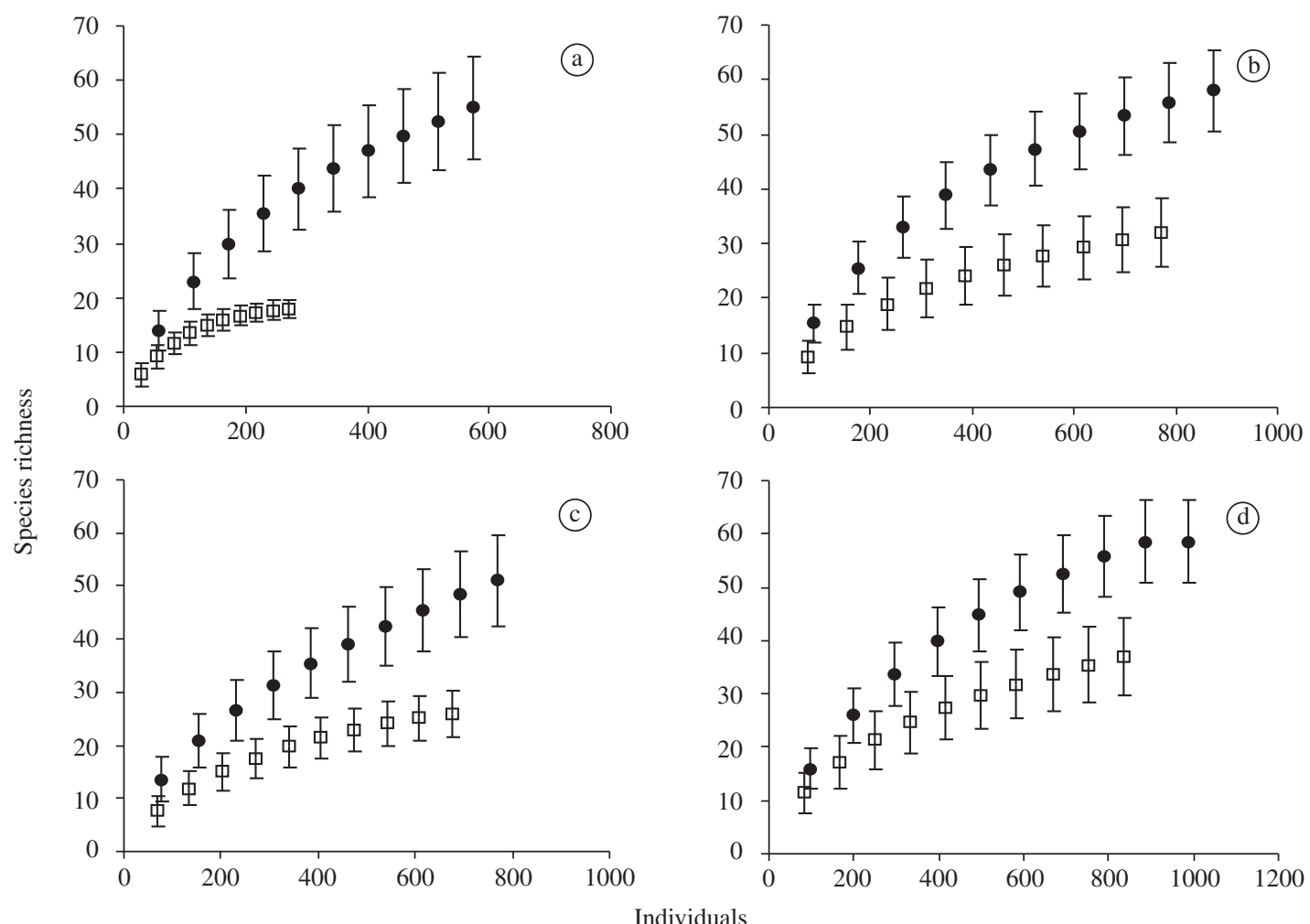

Figure 3. Species richness vs. number of individuals collected in the seasonal cerrado $(\bullet)$ and hyperseasonal cerrado $(\square)$ Emas National Park, Goiás, central Brazil. Vertical bars are $\pm 95 \%$ confidence intervals. a) February, mid rainy season; b) May, late rainy season; c) August, dry season; and d) November, early rainy season.
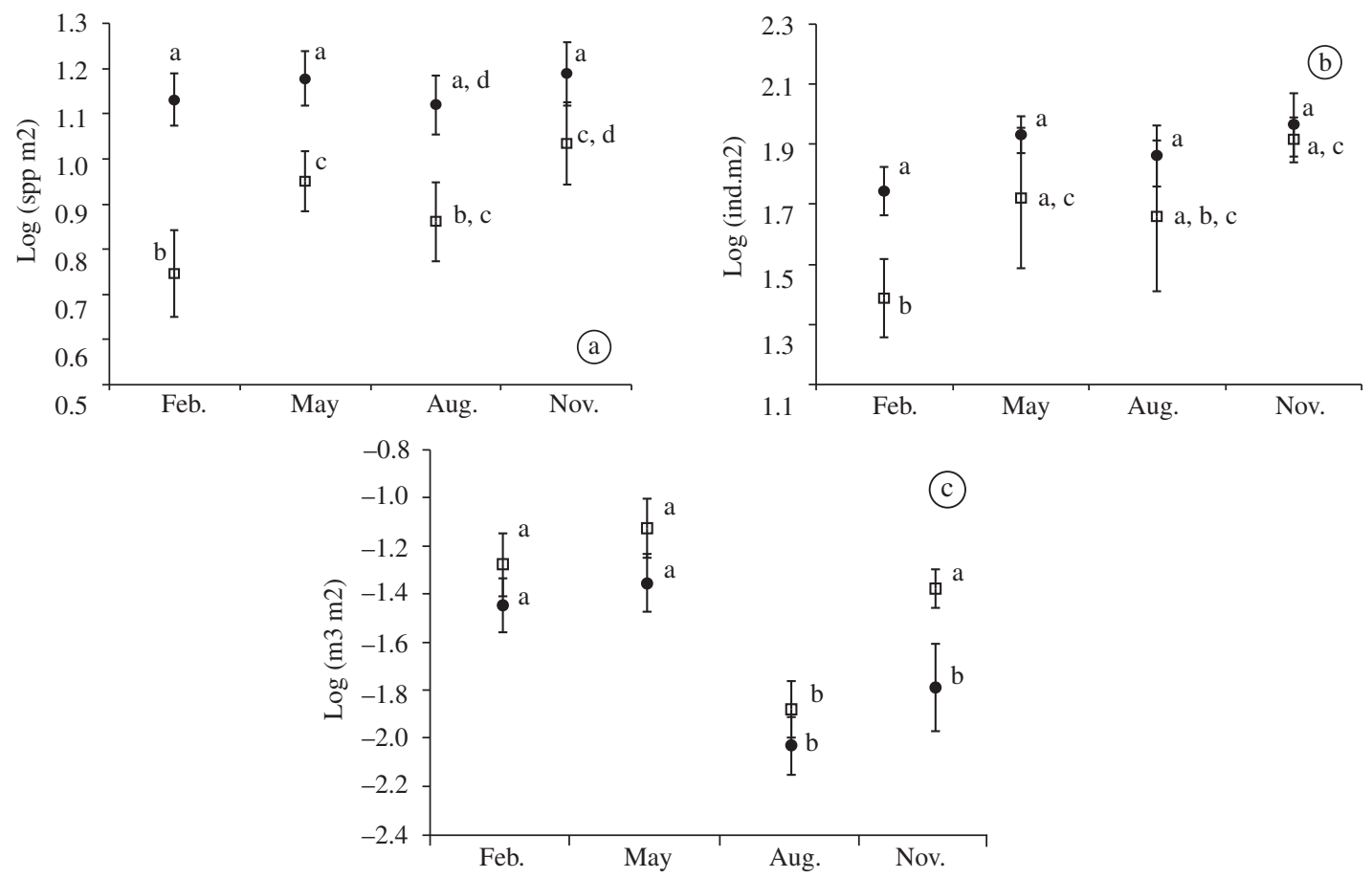

Figure 4. a) Species density; b) plant density; and c) cylindrical volume in the seasonal cerrado (•) and hyperseasonal cerrado ( $\square$ ), in Emas National Park, central Brazil, in four seasons. Feb.) February, mid rainy season; May) late rainy season; Aug.) August, dry season; and Nov.) November, early rainy season. Values are mean $\pm 95 \%$ confidence intervals. Different letters indicate significant differences between means $(\alpha=0.05)$. 
(Ramos-Neto and Pivello, 2000). We found in all seasons high cylindrical volume percentages of the perennial grasses T. leiostachya in the seasonal cerrado and A. leucostachyus in the hyperseasonal cerrado. Thus, in the ENP, not only the seasonal cerrado grasslands are monodominant, but the hyperseasonal cerrado is as well (Cianciaruso et al., 2005); in this case, probably due to waterlogging, since the genus Andropogon also prevails in hyperseasonal savannas of the Colombian and Venezuelan llanos (Sarmiento, 1984).

The herbaceous component should present its greatest development in late rainy season and lowest in the dry season, which is related with the soil PAM (Sarmiento, 1984; Quesada et al., 2004; Sarmiento et al., 2004). In the cerrado vegetation, grasses are dormant in the dry season, and new growth occurs only after the onset of the rainy season (Quesada et al., 2004). Considering the cylindrical volume as a reasonable biomass estimator for cerrado plants (Batalha et al., 2001), the seasonal cerrado reached its biomass peak at mid rainy season, maintaining it until late rainy season, whereas the hyperseasonal cerrado reached its peak at early rainy season and, despite the waterlogging, maintained it until late rainy season (Cianciaruso et al., 2005). So, the hyperseasonal cerrado may be as productive as the seasonal cerrado, contrary to what was found in Venezuelan llanos, where hyperseasonal savannas are $30 \%$ more productive than seasonal ones (Sarmiento and Vera, 1979).

There is a hierarchy of determinants, some of them correlated to others, that affects species composition and diversity of savanna communities (Silva, 1996). At the top of the hierarchy, there is the annual regime of PAM, but other determinants, such as available nutrients, fire, and herbivory, must be considered (Silva, 1996). Short-term changes and period pulsation of these determinants may alter species composition and diversity, but species within functional groups are not entirely equivalent and, hence, they have different tolerances to environmental pulsation (Sarmiento, 1996). Therefore, changing conditions may result in a certain degree of floristic replacement, without major changes in the functioning of the system. This means that savannas should be more stable in functional than in floristic terms (Sarmiento, 1996). In the hyperseasonal cerrado, the two stressing moments, drought and waterlogging, determined the community structure. The hyperseasonal cerrado was more dynamic - in terms of floristic and structural changes - than the seasonal cerrado. Our results corroborated the idea proposed by Sarmiento (1996) and Silva (1996) that changes in the short-term determinants of savannas will affect their floristic composition and community structure.

Acknowledgements - We are grateful to Fapesp, for financial support; to Capes, for the scholarship granted to the first author; to Ibama, for research permission; to the Emas National Park staff, for logistical assistance; to P.K. Amorim, C.A. Casali, A.V.F. Jardim, H.F. Lima, R.A. Miotto, F. Oliveira, I.A. Silva, O.L. Silva, and M.Willik, for help in the field; and to T.S. Filgueiras, R.C. Oliveira, and M.A. Silva, for their assistance in species identification. W. Mantovani and C.H.B.A. Prado provided constructive comments on an earlier draft of this manuscript.

\section{References}

AMORIM, PK. and BATALHA, MA., 2006. Soil characteristics of a hyperseasonal cerrado compared to a seasonal cerrado and a floodplain grassland: implications for plant community structure. Revista Brasileira de Biologia = Brazilian Journal of Biology, vol. 66, no. 2B, p. 661-670.

ANDERSON, MJ., 2001. A new method for non-parametric multivariate analysis of variance. Austral Ecology, vol. 26, no. 1 , p. 32-46.

ANDERSON, MJ., 2003. NPMANOVA: a FORTRAN computer program for non-parametric multivariate analysis of variance (for any two-factor ANOVA design) using permutation tests. New Zealand: Department of Statistics; University of Auckland. Available from: <http://www.stat.auckland.ac.nz/ mja >

ANDERSON, MJ. and WILLIS, TJ., 2003. Canonical analysis of principal coordinates: a useful method of constrained ordination for ecology. Ecology, vol. 84, no. 2, p. 511-525.

BARUCH, Z., 1994. Responses to drought and flooding in tropical forage grasses: I. Biomass allocation, leaf growth and mineral nutrients. Plant Soil, vol. 164, no. 1, p. 87-96.

BARUCH, Z., BELSKY, AJ., BULLA, L., FRANCO, CA., GARAY, I., HARIDASAN, M., LAVELLE, P., MEDINA, E. and SARMIENTO, G., 1996. Biodiversity as regulator of energy-flow, water use and nutrient cycling in savannas. In SOLBRIG, OT., MEDINA, E., SILVA, JF. (Eds.). Biodiversity and savanna ecosystem. Berlin: Springer.

BATALHA, MA., CIANCIARUSO, MV., SILVA, IA. and DELITTI, WCB., 2005. Hyperseasonal cerrado, a new Brazilian vegetation form. Revista Brasileira de Biologia $=$ Brazilian Journal of Biology, vol. 65, no. 4, p. 735-738.

BATALHA, MA. and MARTINS, FR., 2002. The vascular flora of the cerrado in Emas National Park (Goiás, Central Brazil). Sida, vol. 20, no. 1, p. 295-311.

BATALHA, MA., MANTOVANI, W. and MESQUITA Jr, HN., 2001. Vegetation structure in cerrado physiognomies in southeastern Brazil. Revista Brasileira de Biologia $=$ Brazilian Journal of Biology, vol. 61, no. 3, p. 475-483.

BRAY, JR. and CURTIS, JT., 1957. An ordination of the upland forest communities of southern Wisconsin. Ecological Monographs, vol. 27, no. 4, p. 325-349.

CASTRO, AAJF., MARTINS, FR., TAMASHIRO, JY. and SHEPHERD, GJ., 1999. How rich is the flora of Brazilian cerrados? Annals of the Missouri Botanical Garden, vol. 86, no. 1 , p. 192-226.

CHAO, A., CHAZDON, RL., COLWELL, RK. and SHEN, TJ. 2005. A new statistical approach for assessing compositional similarity based on incidence and abundance data. Ecology Letters, vol. 8, no. 2, p. 148-159.

CHASE, JM., 2003. Community assembly: when should history matter? Oecologia, vol. 136, no. 4, p. 489-498.

CIANCIARUSO, MV., BATALHA, MA., SILVA, IA., 2005. Seasonal variation of a hyperseasonal cerrado in Emas National Park, central Brazil. Flora, vol. 200, no. 4, p. 345-353.

CLARKE, KR., 1993. Non-parametric multivariate analyses of changes in community structure. Australian Journal of Ecology, vol. 18 , no. 1 , p. 117-143. 
COLWELL, RK., 2005. EstimateS: Statistical estimation of species richness and shared species from samples. Version 7.5. User's Guide and application. Available from: <http://purl.oclc. org/estimates>.

COLWELL, RK., MAO, CX. and CHANG, J., 2004. Interpolating, extrapolating, and comparing incidence-based species accumulation curves. Ecology, vol. 85, no. 1-3, p. 2717-2727.

FAITH, DP., MINCHIN, PR. and BELBIN, L., 1987. Compositional dissimilarity as a robust measure of ecological distance. Vegetatio, vol. 69, no. 3, p. 57-68.

FJELDSAÅ, J. and LOVETT, J., 1997. Biodiversity and environmental stability. Biodiversity and Conservation, vol. 6, no. 3 , p. 315-323.

FRANCO, AC., 2002. Ecophysiology of woody plants. In OLIVEIRA, PS. and MARQUIS, RJ. (Eds.). The Cerrados of Brazil: ecology and natural history of a neotropical savanna. New York: Columbia University.

FRANCO, AC. and NOBEL, PS., 1990. Influences of root distribution and growth on predicted water uptake and interspecific competition. Oecologia, vol. 82, p. 151-157.

JACKSON, MB., 1979. Rapid injury to peas by soil waterlogging. Journal of the Science of Food and Agriculture, vol. 30 , no. 2 , p. 143-152

JACKSON, MB. and DREW, MC., 1984. Effects of flooding on growth and metabolism of herbaceous plants. In KOSLOWSKI, TT. (Ed.). Flooding and plant growth. New York: Academic.

JOLY, CA., 1991. Adaptações das plantas de savanas e florestas neotropicais a inundação. In SARMIENTO, G. (Ed.). Las sabanas americanas: aspectos de su biogeografia, ecología y utilizacíon. Caracas: Fondo editorial Acta Científica Venezoelana.

KIER, G., MUTKE, J., DINERSTEIN, E., RICKETTS, TH., KÜPER, W., KREFT, H. and BARTHLOTT, W., 2005. Global patterns of plant diversity and floristic knowledge. Journal of Biogeography, vol. 32, no. 7, p. 1107-1116.

KÖPPEN, W., 1931. Grundriss der Klimakunde. Berlin: Gruyter.

KRUSKAL, JB., 1964. Multidimensional scaling by optimizing goodness of fit to a nonmetric hypothesis. Psychometrika, vol. 29 , no. 1 , p. $1-27$

LEYSHON, AJ. and SHEARD, RW. 1974. Influence of shortterm flooding on the growth and plant nutrient composition of barley. Canadian Journal of Soil Science, vol. 54, p. 463-473.

LYONS, KG., BRIGHAM, CA., TRAUT, BH. and SCHWARTZ, MW., 2005. Rare species and ecosystem functioning. Conservation Biology, vol. 19, no. 4, p. 1019-1024.

MALIK, AI., COLMER, TD., LAMBERS, H., SCHORTEMEYER, M., 2001. Changes in physiological and morphological traits of roots and shoots of wheat in response to different depths of waterlogging. Australian Journal of Plant Physiology, vol. 28, no. 11, p. 1121-1131.

MENDONÇA, RC., FELFILI, JM., WALTER, BMT., SILVAJÚNIOR, MC., REZENDE, AV., FILGUEIRAS, TS. and
NOGUEIRA, PE., 1998. Flora vascular do Cerrado. In SANO, SM. and ALMEIDA, SP. (Ed.). Cerrado: ambiente e flora. Brasília: Embrapa.

OLIVEIRA, RS., BEZERRA, L., Da VIDSON, EA., PINTO, F., KLINK, CA., NEPSTAD, DC. and MOREIRA, A., 2005. Deep root function in soil water dynamics in cerrado savannas of central Brazil. Functional Ecology, vol. 19, no. 4, p. 574-581.

QUESADA, CA., MIRANDA, AC., HODNETT, MG., SANTOS, AJB., MIRANDA, HS. and BREYER, LM. 2004. Seasonal and depth variation of soil moisture in a burned open savanna (campo sujo) in central Brazil. Ecological Applications, vol. 14, Suppl.: LBA Experiment, p. S33-S41.

RAMOS-NETO, MB. and PIVELLO, VR., 2000. Lightning fires in a Brazilian savanna National Park: rethinking management strategies. Environmental Management, vol. 26, p. 675-684.

RATTER, JA., RIBEIRO, JF. and BRIDGEWATER, S., 1997. The Brazilian cerrado vegetation and threats to its biodiversity. Annals of Botany, vol. 80, no. 3, p. 223-230.

SARMIENTO, G., 1984. The ecology of Neotropical savannas. Cambridge: Harvard University. 256p.

1992. Adaptative strategies of perennial grasses in South American savannas. Journal of Vegetation Science, vol. 3, no. 3, p. 325-336.

1996. Biodiversity and water relations in tropical savannas. In SOLBRIG, OT., MEDINA, E. and SILVA, JF. (Eds.). Biodiversity and savanna ecosystem. Berlin: Springer.

SARMIENTO, G. and VERA, M., 1979. Composicion, estructura, biomasa y production primaria de diferentes sabanas em los llanos occidentales de Venezuela. Boletín Sociedad Venezolana de Ciencias Naturales, vol. 136, p. 5-41.

SARMIENTO, G. and MONASTERIO, M., 1975. A critical consideration of the environmental conditions associated with the occurrence of savanna ecosystems in tropical America. In GOLLEY, FB. and MEDINA, E. (Eds.) Tropical ecological systems. New York: Springer.

SARMIENTO, G., PINILLOS, M., SILVA, MP. and ACEVEDO, D., 2004. Effects of soil water regime and grazing on vegetation diversity and production in a hyperseasonal savanna in the Apure Llanos, Venezuela. Journal of Tropical Ecology, vol. 20, no. 2, p. 209-220.

SILVA, IA. and BATALHA, MA., 2006. Taxonomic distinctness and diversity of a hyperseasonal savanna in central Brazil. Diversity and Distributions, vol. 12, no. 6, p. 725-730.

SILVA, JF., 1996. Biodiversity and stability in tropical savannas. In SOLBRIG, OT., MEDINA, E. and SILVA, JF. (Eds.). Biodiversity and savanna ecosystem. Berlin: Springer.

United Nations Educational, Scientific, and Cultural Organization - UNESCO, 2001. Cerrado protected areas: chapada dos Veadeiros and Emas National Parks. Paris. Available from: <http://www.unesco.org/whc/sites/1035.htm>.

ZAR, JH., 1999. Biostatiscal analysis. Prentice Hall: Upper Saddle River. 